\title{
Teaching Political Theory at a Prison in South Texas
}

\author{
William W. Sokoloff, University of Texas, Pan American
}

ABSTRACT Taking students to a prison for a field trip creates an opportunity to engage students on issues central to democratic citizenship including democracy, power, and punishment. Although some students opt out of the prison visit, a field trip to a prison creates a vibrant learning environment where students can share their experience with other classmates as well as reflect on their experiences with authority figures. It also disrupts power relationships between students and instructors because all prison field trip participants are virtual inmates for a day.

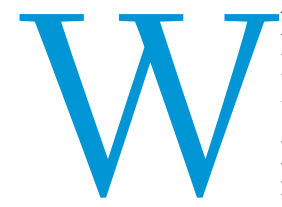
hen I was in the eighth grade, I visited Folsom Prison on a weekend school-organized field trip. Although we stayed on the outside of the prison, I was intrigued by the prison. I saw an inmate sweeping the entrance and recall his somber facial expression and body language, the razor wire, prison walls, and the armed guards. No discussion of the prison visit took place before, during, or after the trip. Even so, I am grateful to have had the opportunity to visit Folsom Prison and have decided to continue the tradition by taking my students to a prison. Why take university students to prison?

Taking students to a prison on a field trip creates a studentcentered learning environment where students can use a personal experience to connect theory with practice and discuss the issues that are important to them; it leads to heated discussions about the role of prisons in the United States; it stimulates critical thinking leading to a discussion of the similarities between educational institutions and the modern prison; it levels the playing field between instructor and student because both are virtual inmates for a day; it can also increase trust between students and faculty that is needed for mentoring.

My current academic position working with nontraditional and at-risk students has taught me that an experimental approach to teaching is an effective strategy to help students succeed in the classroom. I work at the largest Hispanic serving institution (HSI) in Texas, the University of Texas, Pan American (UTPA), which is located approximately 10 miles from the US/Mexico border in Edinburg, Texas. UTPA has a student population of approximately 19,00o, serves mainly first-generation university students, and has a predominantly Latino/a student population (88.7\%), many of whom have not been adequately prepared to succeed at the university. The Rio Grande Valley is one of the poorest metropolitan centers in the United States with a low high school completion rate and a high teenage pregnancy rate. Many of our students are English

William W. Sokoloff is an assistant professor and teaches political theory in the department of political science at the University of Texas, Pan American. He can be reached atwwsokoloff@utpa.edu. language learners from economically disadvantaged backgrounds. In addition, many of our students work part- or full-time jobs and have responsibilities taking care of a child, parent, grandparent, sibling, or other relatives. Many students also commute to UTPA from long distances, and some of them are Mexican nationals who are delayed at border crossing stations.

Many UPTA students underestimate themselves, have not been challenged academically, and have limited experience travelling outside the Rio Grande Valley. The student faculty ratio at UTPA is $25: 1$, one of the highest among state universities, making it difficult for faculty to provide optimum attention to students. South Texas education based on teaching to the test has left many of our students ill-prepared for critical and analytical thinking, argumentation, and intellectual synthesis skills (Volante 2004). Even among UTPA political science majors, students have a difficult time formulating argumentative essays, can be fearful about challenging even a weak argument, and adopt a passive and uncritical mindset in relation to the reading material. Given the complicated character of the lives of our students and their lack of preparation to succeed at a university, this translates into poor academic performance that goes far beyond the structural-institutional factors Arum and Roska (2011) argue account for limited learning on university campuses.

The failure rate for the introductory US and Texas government and politics courses offered to about 5,0oo students per academic year at UTPA is approximately $30 \%$, a concern to faculty and administrators that has led to heated discussions about who is responsible and what should be done to improve academic performance. A recent article argued that the ways in which the lives and achievements of Latino/a Americans are portrayed or left out of mainstream American government texts may play a part in low academic performance (Lavariega Monforti and McGlynn 2010). How can faculty stimulate interest in course material among a complicated student population?

\section{PEDAGOGICAL THEORY}

Teaching requires having a perspective, valuing certain ideas, and denying value to other ideas. Consider the values involved with the selection of reading material by the teacher, whether these readings reinforce or challenge the political status quo, the range 
of perspectives explored, the perspective from which ideas are analyzed, the amount of time spent on one theme as opposed to another, and the interpersonal relationships between faculty and students. All of this involves modes of valuation and investments in particular perspectives (Nietzsche 1989).

Given the inescapable perspectival character of teaching practices, the question is how best to engage and motivate students to succeed who come from environments that hinder their chances for academic achievement and who have historically underachieved in academic contexts (Pizarro 2005; Wlodkowski 2008). Clearly, what is taught in courses on democracy and citizenship is as important as how it is taught (Freire 2010; Halliday 1999; Jansen, Chioncel, and Dekkers 2006; Lawy and Biesta 2006; Pizarro 2005; Westheimer and Kahne 2004). Freire's (2010) work effectively explores the "what to teach?" and "how to teach?" questions and provides a rationale for a new way of educating at-risk students.

Freire (2010) contrasts two forms of education, one that is liberating, another that is oppressive. Education becomes a form of oppression, according to Freire (2010), when it is based on the "banking concept of education" where faculty knowledge is transmitted to "ignorant" students (Freire 2010, 72). The educator "decrees the ignorance of someone else" from a position of superiority (Freire 2010,134). This style of teaching is flawed, according to Freire (2010), because it transforms students into passive objects who are silenced.

In contrast to an education that oppresses, Freire (2010) argues for an education that liberates and develops the critical consciousness of students. A liberating education is a dialogical one that expands the scope of action allowed to students. It is intended to help students see how they exist in the world, help students learn to affirm and value their experiences, and stimulate their creative power via a participatory educational praxis. Freire (2010) calls for a pedagogical revolution in education based on the idea of a comradeship with the oppressed (see also Boyle 2010). If at-risk students are lethargic and unmotivated, this is the product of social, economic, and political domination (Freire 2010). and students by putting both in a situation where they are relatively equal during the prison visit. This arguably helps students feel more comfortable discussing the issues that are important to them. Freire (2010) and Pizarro's (2005) research on pedagogy leads to a justification for a prison field trip. A prison visit disrupts traditional power relations in the classroom and potentially creates comradeship with students. A prison visit also allows students to discuss the issues that are important to them so that they could use their education to address the needs of their communities. There are other reasons for taking students to a prison.

The prison, as both metaphor and reality, occupies a central place among political theorists, film-makers, and activists and is present in popular culture. Plato (1992) foregrounded the prisonlike character of the lack of education in the allegory of the cave in The Republic. Nietzsche (1989) explored the question of punishment in On the Genealogy of Morals, which of course, influenced Foucault's (1979) Discipline and Punish. In Pontecorvo's "Battle of Algiers," the male protagonist Ali la Pointe receives some of his political education in a prison as an inmate imprisoned for petty criminal activity. As portrayed in the film, La Pointe witnesses the guillotine execution of an Algerian inmate and achieves political consciousness through that event and via conversations with other inmates. In addition, many great thinkers, political activists, and politicians had trouble with local authorities and spent time in jail. Finally, there is popular interest in gangs, prison life, and the criminal element. Students tell me they watch or know about television programs such as Locked-Up Abroad and Gangland.

As opposed to trying to force my students out of Plato's cave, I turn Plato on his head and take willing students on a field trip to prison to explore themes including democracy, power, and punishment. In my upper-division course Contemporary Political Theory, I schedule a visit to a local prison on a Friday afternoon into the outline of possible course activities listed in the syllabus. One of the course learning objectives is: "Apply the ideas and themes in this class to our current political context." Taking students to a

\section{Taking students on a field trip to a prison not only allows students to interact with their faculty member outside of the arguably sterile classroom setting but it levels the playing field between faculty and students by putting both in a situation where they are relatively equal during the prison visit.}

Latinos/as could be considered at-risk because they face the highest dropout rates of any major ethnic group in the United States (Pizarro 2005; 13). High teenage pregnancy rates, gang involvement, drug abuse, and incarceration compound this problem. For Pizarro (2005), low educational attainment will continue as long as Latino/a students are not seen as political agents in their schools and communities (3). Of the Latinos/as who manage to stay in school, Pizarro (2005) argues a new approach to teaching is needed to keep them there. For Pizarro, Latinos/as need to be allowed to discuss the issues that are important to them in the classroom, especially their experiences as a marginalized minority group $(2005,27)$. Taking students on a field trip to a prison not only allows students to interact with their faculty member outside of the arguably sterile classroom setting but it levels the playing field between faculty local prison is intended to at least partially fulfill this learning objective. The prison visit also serves as an experience that allows students to share their observations and connect their experiences with course material.

\section{DEDICATED TO IMPROVING LIVES}

On November 4, 2011, I took 30 UTPA students to a jail. Located in Edinburg, Texas, Reynoldo V. Lopez State Jail has a maximum capacity of 1,100 inmates, and 262 total employees; and inmates are serving relatively short-term sentences (five years) for a variety of offenses including burglary, driving while intoxicated, robbery, aggravated assault and robbery, and drug possession/trafficking (Lopez Unit Demographics 2013). (See figure 1 and 2.) According to their website, Lopez State Jail offers educational programs in 


\section{Figure 1}

\section{Reynoldo V. Lopez State Jail Entrance Sign}

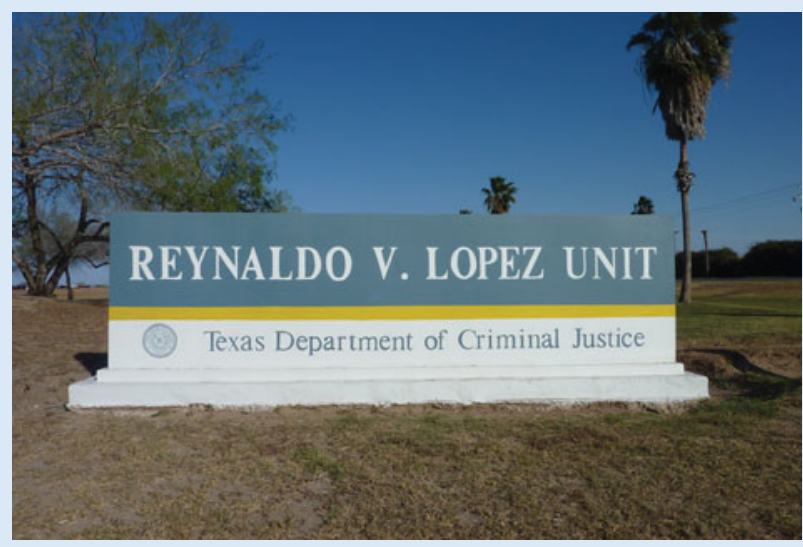

Photo by William W. Sokoloff.

literacy (GED), CHANGES/Pre-Release, and Cognitive Intervention. More than $60 \%$ of inmates at Lopez Jail are Hispanic, approximately $20 \%$ are black, and $14 \%$ are white (Lopez Unit Demographics 2013).

As student participants arrived at the prison, they gathered in the parking lot. Shortly thereafter, we were welcomed by a prison guard. We then walked as a group to the main entrance. After participants passed through a metal detector, we were searched and surrendered our identification. Next, participants were addressed by the warden in the area where inmates meet and speak with visitors. At this point in the visit, a male student was ejected from the facility by the warden for a dress code violation (ripped jeans).

Participants were escorted to the entrance of the main prison inmate housing area and passed a sign that reads "NO NEGOTIATION WITH HOSTAGES," passed through another threshold, and then entered the main prison facility. During the three-hour tour, participants observed a demonstration of prison contraband (tattoo machines, prison ink, weapons, and "shanks"). Participants reported being impressed by the creativity and ingenuity of the inmates. Participants toured the inmate medical center, the yard, eating areas, educational facilities, and inmate housing units. Participants learned that the unarmed guards monitoring inmates wear goggles as protection against blood, feces, semen, and urine that may be thrown into the eyes of the prison guards by angry inmates. Willing participants were also briefly locked up in a vacant out-ofservice prisoner cell.

Participants reported being startled by conditions in the prison. (See figure 3.) There is no air conditioning in the inmate housing units, and the units have metal roofs (summers in South Texas are hot, with highs averaging more than 100 degrees $\mathrm{F}$ for months); we learned breakfast was served at 3:00 a.m.; the prison was filled with thundering echoes when doors were closed; the environment was sterile, with concrete floors and thick metal doors. The scent of industrial strength chemical cleaning agents permeated the facility.

After the three-hour tour, participants gathered in the parking lot, but departed quickly, because it is against prison rules for meetings to be held in the parking lot. Although I did not do this, it might be useful to set up an alternative meeting place for a postprison visit debriefing with students. When a normal class session resumed the following week, students shared their experience with the class.
As Grefe (2008) suggests, students could be asked to write a letter from a family member from the vantage point of a prison inmate describing their life in prison; students could write a memo as a legislator advocating prison reform that focuses on the problems that participants observed; students could be asked to evaluate the living conditions in jail from the perspective of a human rights activist.

In my course, not all students were able to participate on the field trip so these assignments would be unfair to students who did not attend. Nevertheless, student participants were happy to discuss their experience with the class. In fact, I had a hard time keeping the discussion focused given the level of excitement about the prison field trip. In this respect, taking students to the prison on a field trip created a student-centered learning environment, where students can discuss the issues that are important to them, which research has shown is most likely to improve student academic success (Archer and Miller 2011; Howard 2003; Ladson-Billings 1995; Lima and Gazzetta 1994; Osborne 1996; Soper 2010).

\section{PRISON FIELD TRIP READING ASSIGNMENTS}

Before the prison visit, a class discussion explored assumptions we have about conditions in prisons. Before students share their ideas with the class, students write down these preconceptions and hand them in. Preprison visit perceptions could be used after the prison visit to assess how these perceptions differed from postprison field trip perceptions. Additionally, students read Nietzsche's On the Genealogy of Morals (1989) and a chapter from Villa's Socratic Citizenship (2001). These texts were chosen to analyze justifications for punishment (Nietzsche) and highlight the contrast between engaged citizenship and prisoner subjection (Villa). In terms of the reading material by Villa (2001), we explored the idea of the prison as the space of political death, because felons are denied the right

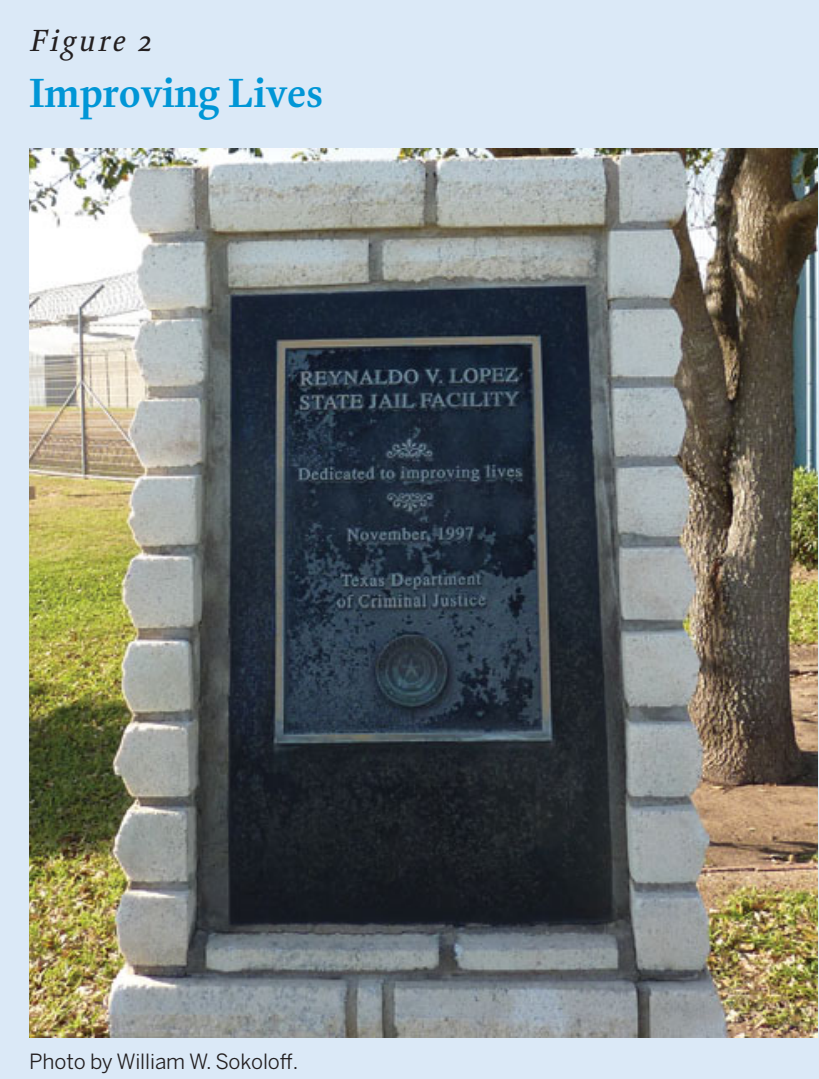




\section{Figure 3}

Front of Reynoldo V. Lopez State Jail

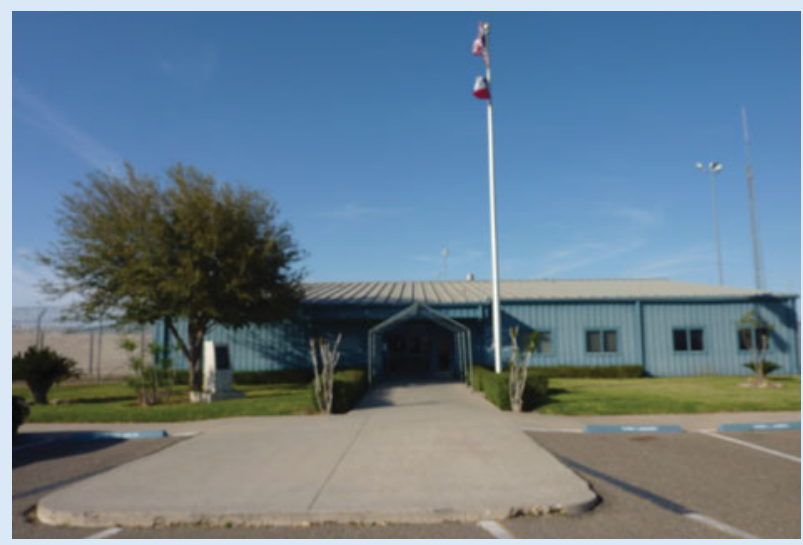

Photo by William W. Sokoloff.

to vote, although felon disenfranchisement varies from state to state in the United Statesand depends on the character of crime committed.

Students were encouraged to use the reading material to analyze what they observed during the prison visit. Students also had the option of including their insights drawn from the prison visit in their required argumentative essays. In terms of the impact of the prison field trip on student performance, students who included references to the prison visit in their essays demonstrated greater mastery of course material and a higher level of enthusiasm for the argumentative essay writing assignment. For example, a student informed me that he was better able to understand the mentality of the colonized as depicted in Fanon's The Wretched of the Earth (2005) as a result of visiting the prison. these objections, the advantages of taking students to a prison that include leveling the playing field between faculty/students, learning about prison conditions, and creating a student-centered learning environment outweigh the disadvantages. All of these possible objections could be discussed with students that could enrich the overall experience of the prison field trip.

Other issues could add to the complexity of planning a prison field trip. Because of prison staffing and security issues, a maximum of 30 students are allowed to visit the prison. If class size is more than 30 , faculty members will have to tell some interested students that they are not able to participate. This issue may not be possible to overcome because the number of participants is externally dictated by a prison's policies on educational tours.

Nevertheless, visiting a prison can create a learning environment where students are more comfortable discussing the issues that are important to them. In terms of the learning objectives of the course, all students were able to fulfill objectives pertaining to the application of theory to practical situations (for example, students were asked to explain what Nietzsche would say about the prison conditions we observed), critical thinking (students were asked to compare and contrast educational institutions with the prison), and critical textual analysis (students were asked to analyze the strengths and weakness of Nietzsche's view on punishment) as a result of the participation of a large segment of a class on the field trip.

\section{CONCLUSION}

Students need to know that their voice and experiences are essential components in understanding their role as active citizens in a democracy and as active participants in their education (Freire 2010; Pizarro 2005). Taking students to a prison provides a unique opportunity to stimulate student engagement and create a student-centered learning environment defined as giving students the opportunity

\section{Students were encouraged to use the reading material to analyze what they observed during the prison visit. Students also had the option of including their insights drawn from the prison visit in their required argumentative essays.}

\section{REFUTATION OF OBJECTIONS}

Although I believe the advantages of a prison field trip outweigh the disadvantages, it is important to specify possible disadvantages. The prison is arguably terrifying and could be traumatizing for a student and a faculty member. Also, participants could be accused of treating the inmates as exotic subjects, like animals in cages at a human zoo. These are legitimate points, but the interest in learning about prison conditions outweighs these risks. Faculty need to be aware of the possibility of inappropriate student conduct during the visit. Curious inmates were jeering and pointing at the participants, especially the female students. As participants walked in a corridor away from the inmates, a female student pretended to lift up the front of her blouse but stopped when she noticed I saw this.

Ethically, it could be asked if prison field trip participants are exploiting the prisoners as an opportunity for learning for privileged (in comparison to the prisoners) students. It could also be asked if taking students to a prison is a shock-therapy approach to teaching with short-term impact but dubious long-term value. While I respect to discuss the issues that are important to them. It also creates a an environment where students can use a personal experience to connect theory with practice; it leads to heated discussions about the role of prisons in the United States; it levels the playing field between student and professor because both are inmates for a day; and it can encourage students to share their own experiences with the police and other authority figures.

Recently, I contacted student prison field trip participants via e-mail. I posed the following questions: please write a paragraph (or more if possible) describing what you learned from the prison visit, how it impacted your performance in the course, whether you thought it was a positive or negative experience and why, and anything else you feel comfortable sharing about the visit? One student stated:

I believe the prison visit helped in a great way, it made me open my eyes to how a prison is really like. I watch many shows where delinquents go in for one day and they get to go inside and experience it firsthand like we did, and I thought they were just 
exaggerating but now I know that they weren't. I believe it was a positive experience, even though I know for myself I will never be in jail anytime soon or ever, but it was an experience I will never forget because every time people talk about jail they say some horrific things and now I believe it because I got to experience those things when I went. The way they have no privacy, and a certain schedule in order for them to eat, and the way that like about six people had to share one cell, including the restroom. The stories that the guards would tell us were also very interesting and unbelievable because I never thought people were that messed up to do the things that they did. It was very interesting the way that they had to be standing against a wall and not make any eye contact whenever we passed by. I also like the fact that the people in prisons had many opportunities to shape up their lives even if they were in jail. I liked that they could take classes and do volunteer work. It was a scary experience at first because of the way some prison members treated us, like screamed at us and made these noises when they saw us but the experience overall was worth it. They should have programs that can take high school students or even middle school kids to jail so that more and more children will experience the negativity of going to jail so that they will get their lives together and shape up their lives before it is too late.

Although the student did not connect the prison experience with specific reading material, the statement is loaded with details pertaining to the prison field trip (written more than 15 months after the visit to Lopez Jail!), as well as a policy recommendation about taking younger students to correctional facilities.

Based on a field trip to a prison on November 4, 2011, my experience indicates that students are more willing to argue and participate in class when the material and class activities are controversial and relevant to their own experience. Analyzing the relationship between democracy and punishment in a prison is a great way to begin a conversation with students about core political concepts. Because students and faculty share an experience, the prison field trip can increase the level of trust between them that is needed for mentoring. The field trip can also be a form of education as social justice rather than education being about social justice (see Pizarro 2005, 266). The prison visit opens a space for students to discuss what is important to them, it disrupts traditional authority relations between students and faculty, and it stimulates critical reflection on one of the fastest growing industries in America.

\section{ACKNOWLEDGMENTS}

I thank Stanley Gonzales at UTPA for assistance with the prison field trip. I also thank Warden Rios for the opportunity to visit the correctional facility. Finally, I thank Amanda Iglesias for research assistance.

\section{REFERE N C E S}

Archer, Candace C, and Melissa K. Miller. 2011. "Prioritizing Active Learning: An Exploration of Gateway Courses in Political Science." PS: Political Science and Politics 44 (2): 429-34.

Arum, Richard, and Josipa Roksa. 2011. Academically Adrift: Limited Learning on College Campuses. Chicago: University of Chicago Press.
Boyle, Gregory. 2010. Tattoos on the Heart: The Power of Boundless Compassion. New York: Free Press.

Cantellas, Miguel. 2010. "Pop Culture in the Classroom: American Idol, Karl Marx, and Alexis de Tocqueville." PS: Political Science and Politics 43 (3): 561-73.

Davis, James. 2007. “Dialogue, Monologue and Soliloquy in the Large Lecture Class." International Journal of Teaching and Learning in Higher Education 19 (2): 178-82.

Dreyer, David R, 2011. "Learning from Popular Culture: The "Politics" of Competitive Reality Television Programs." PS: Political Science and Politics $44(2): 409-13$

Fanon, Frantz. 2005. The Wretched of the Earth. Trans. Richard Philcox. New York: Grove Press.

Foucault, Michel. 1979. Discipline and Punish. Trans. Alan Sheridan. New York: Vintage Books.

Freire, Paulo. 2010. Pedagogy of the Oppressed. Trans. Myra Bergman Ramos. New York Continuum.

Grefe, Morgan C. 2008. "Making Prison History Matter: Field Trips and Lessons for History and Civics." Connecticut History 47 (1): 132-36.

Halliday, John. 1999. "Political Liberalism and Citizenship Education: Towards Curriculum Reform.” British Journal of Educational Studies 47 (1): 34-55.

Howard, Tyrone C. 2003. "Culturally Relevant Pedagogy: Ingredients for Critical Teacher Reflection.” Theory into Practice 42 (3): 195-202.

Jansen, Th., N. Chioncel, and H. Dekkers. 2006. "Social Cohesion and Integration: Learning Active Citizenship." British Journal of Sociology of Education 27 (2): 189-205

Ladson-Billings, Gloria. 1995. "Toward a Theory of Culturally Relevant Pedagogy." American Educational Research Journal 32 (3): 465-91.

Lavariega Monforti, Jessica, and Adam McGlynn. 2010. "Aquí Estamos? A Survey of Latino Portrayal in Introductory U.S. Government and Politics Textbooks." PS: Political Science and Politics 43 (2): 309-16.

Lawy, Robert, and Gert Biesta. 2006. "Citizenship as Practice: The Educational Implications of an Inclusive and Relational Understanding of Citizenship." British Journal of Educational Studies 54 (1): 34-50.

Lima, Elvira Souza, and Marineusa Gazzetta. 1994. "From Lay Teachers to University Students: The Path for Empowerment through Culturally Based Pedagogical Action." Anthropology and Education Quarterly 25 (3): 236-49.

“Lopez Unit Demographics.” 2013. Texas Department of Criminal Justice. Huntsville, Texas.

Nietzsche, Friedrich. 1989. On the Genealogy of Morals. Trans. Walter Kaufmann and R. J. Hollingdale. New York: Vintage.

Omelicheva, Mariya Y. and Olga Avdeyeva. 2008. "Teaching with Lecture or Debate? Testing the Effectivness of Traditional versus Active Learning Methods of Instruction." PS: Political Science and Politics 41 (3): 603-07.

Osborne, Barry A. 1996. "Practice into Theory into Practice: Culturally Relevant Pedagogy for Students We Have Marginalized and Normalized." Anthropology $\mathcal{E}$ Education Quarterly 27 (3): 285-14.

Pizarro, Marcos. 2005. Chicanas and Chicanos in School: Racial Profiling, Identity Battles, and Empowerment. Austin: University of Texas Press.

Plato. 1992. Republic. Trans. G. M. A. Grube and C. D. C. Reeve. Indianapolis: Hackett.

Pontecorvo, Gillo. 1966. Battle of Algiers. Rome, Italy: Igor Films. Videocassette (VHS), $121 \mathrm{~min}$.

Pulliam, Lloyd. 1963. "The Lecture: Are we Reviving Discredited Teaching Methods?" The Phi Delta Kappan 14 (8): 382-85.

Soper, Christopher. 2010. "Rock and Roll Will Never Die: Using Music to Engage Students in the Study of Political Science." PS: Political Science and Politics 43 (2): 363-67.

Villa, Dana. 2001. Socratic Citizenship. Princeton, NJ: Princeton University Press.

Volante, Louis. 2004. "Teaching to the Test: What Every Educator and Policymaker Should Know." Canadian Journal of Educational Administration and Policy 35: 1-7.

Westheimer, Joel, and Joseph Kahne. 2004. "What Kind of Citizen? The Politics of Educating for Democracy." American Educational Research Journal 41 (2): 237-69.

Wlodkowski, Raymond J. 2008. Enhancing Adult Motivation to Learn: A Comprehensive Guide for Teaching All Adults. San Francisco: Jossey-Bass. 